\title{
Species Identification of Red Deer (Cerous elaphus), Roe Deer (Capreolus capreolus), and Water Deer (Hydropotes inermis) Using Capillary Electrophoresis-Based Multiplex PCR
}

\author{
Mi-Ju Kim, Yu-Min Lee, Seung-Man Suh and Hae-Yeong Kim *(i) \\ Institute of Life Sciences \& Resources and Department of Food Science \& Biotechnology, Kyung Hee University, \\ Yongin 17104, Korea; mijukim79@gmail.com (M.-J.K.); lym5373@naver.com (Y.-M.L.); \\ teri2gogo@naver.com (S.-M.S.) \\ * Correspondence: hykim@khu.ac.kr
}

Received: 26 June 2020; Accepted: 22 July 2020; Published: 23 July 2020

check for updates

\begin{abstract}
To provide consumers correct information on meat species, specific and sensitive detection methods are needed. Thus, we developed a capillary electrophoresis-based multiplex PCR assay to simultaneously detect red deer (Cervus elaphus), roe deer (Capreolus capreolus), and water deer (Hydropotes inermis). Specific primer sets for these three species were newly designed. Each primer set only amplified target species without any reactivity against non-target species. To identify multiple targets in a single reaction, multiplex PCR was optimized and combined with capillary electrophoresis to increase resolution and accuracy for the detection of multiple targets. The detection levels of this assay were $0.1 \mathrm{pg}$ for red deer and roe deer and $1 \mathrm{pg}$ for water deer. In addition, its applicability was demonstrated using various concentrations of meat DNA mixtures. Consequently, as low as $0.1 \%$ of the target species was detectable using the developed method. This capillary electrophoresis-based multiplex PCR assay for simultaneous detection of three types of deer meat could authenticate deer species labeled on products, thus protecting consumers from meat adulteration.
\end{abstract}

Keywords: red deer; roe deer; water deer; multiplex PCR; capillary electrophoresis

\section{Introduction}

The inaccurate information on the meat species in meat products has been globally concerned by consumers and regulatory agencies [1,2]. Since it is illegal to substitute meat species undeclared on the label of meat products, food manufactures must authenticate correct ingredients declared on their products [3,4]. In the meat industry, game meat consumed commercially is more expensive than meat from domesticated animals. This is because game meat has high nutritional value, such as higher protein and lower fat levels. In addition, it does not contain residues of antibiotics or growth hormones $[3,5,6]$. Accordingly, replacing game meat with relatively cheaper domesticated meat has taken place for the economic benefit [5]. For game meat products containing deer species, red deer (Cervus elaphus) and roe deer (Capreolus capreolus) are commonly used, meaning that these species are particularly susceptible to fraudulent labeling [7,8]. Several European countries traditionally permit game hunting [7]. Meanwhile, in Korea, wild animals, such as water deer (Hydropotes inermis), that damage crops can be temporarily hunted. However, their distribution and sale are limited, according to the Ministry of Environment guideline. In addition, water deer cannot be used as raw meat or processed food in Korea. To prevent food adulteration, an authentication method for differentiating red deer, roe deer, and water deer is essential. 
Methods for detecting meat species have been developed based on DNA molecules and proteins [1,9]. Protein-based methods for deer species authentication have been used by enzyme-linked immunosorbent assay (ELISA), high-performance liquid chromatography (HPLC), and liquid chromatography-mass spectrometry (LC-MS) [10-12]. However, the thermal stability of nucleic acids compared to proteins can increase the amplification efficiency of target species in processed foods $[13,14]$. PCR, a representative DNA-based detection method, has been utilized for species identification in various fields [15-18]. For deer species, PCR-based detection methods, such as conventional PCR and real-time PCR, have been developed $[3,8,19]$. To differentiate closely related animal species, the development of specific primers for a target species is very crucial. Mitochondrial DNAs, such as cytochrome b, $12 \mathrm{~S}$ rRNA, and D-loop, are commonly used as target genes due to their sequence variations [2,20-22]. Furthermore, to increase the sensitivity of the DNA-based detection method in processed foods, a short fragment of PCR amplification is required because of DNA degradation during the manufacturing process [22,23]. Meanwhile, a multiplex PCR can simultaneously detect several species in a single reaction tube, resulting in effective detection $[15,24,25]$. Recently, to clearly separate similar sizes of amplicons of short PCR products, multiplex PCR methods combined with capillary electrophoresis have been developed and applied to simultaneously identify various target species $[15,26]$.

The aim of this study was to develop a capillary electrophoresis-based multiplex PCR (CE-mPCR) method to verify the presence of wild animal species, such as red deer, roe deer, and water deer, in processed foods. The developed assay not only saves time and labor because it can simultaneously detect three target species but also can be utilized as a specific and sensitive method for a clear separation of these three species.

\section{Materials and Methods}

\subsection{Sample Preparation}

Raw tissue samples of 10 animal species (red deer: Cervus elaphus, water deer: Hydropotes inermis, roe deer: Capreolus capreolus, beef: Bos taurus, pork: Sus scrofa domestica, lamb: Ovis aries, goat: Capra hircus, horse: Equus caballus, chicken: Gallus gallus, and duck: Anas platyrhynchos) were collected from the Conservation Genome Resource Bank (CGRB, Seoul, Korea) or purchased from online and local markets of Korea. All samples were cut into small pieces and immediately stored at $-20^{\circ} \mathrm{C}$ until analysis.

\subsection{DNA Extraction}

DNAs were extracted from meat samples of animal species and processed products using a DNeasy Blood and Tissue Kit (Qiagen, Hilden, Germany), according to the manufacturer's instructions with slight modifications. For good quality of DNA, $25 \mathrm{mg}$ of meat was ground, and all buffers for extraction were used at double quantity. The purity and concentration of extracted DNAs were measured with a Maestro spectrophotometer (Maestro, Las Vegas, NV, USA). DNAs with a 260/280 nm ratio between 1.8 and 2.0 were used as templates for PCR.

\subsection{Primer Design}

To select species-specific regions for red deer, roe deer, and water deer, nucleotide sequences of target genes of 19 various animals were downloaded from the GenBank database (Table S1) and aligned using Clustal Omega program (http://www.ebi.ac.uk/Tools/msa/clustalo/) (Figure 1). Species-specific primer sets were newly designed using Primer Designer, version 3.0 (Scientific and Educational Software, Durham, NC, USA). Primers used in this study are listed in Table 1. They were synthesized by Bionics (Seoul, Korea). 


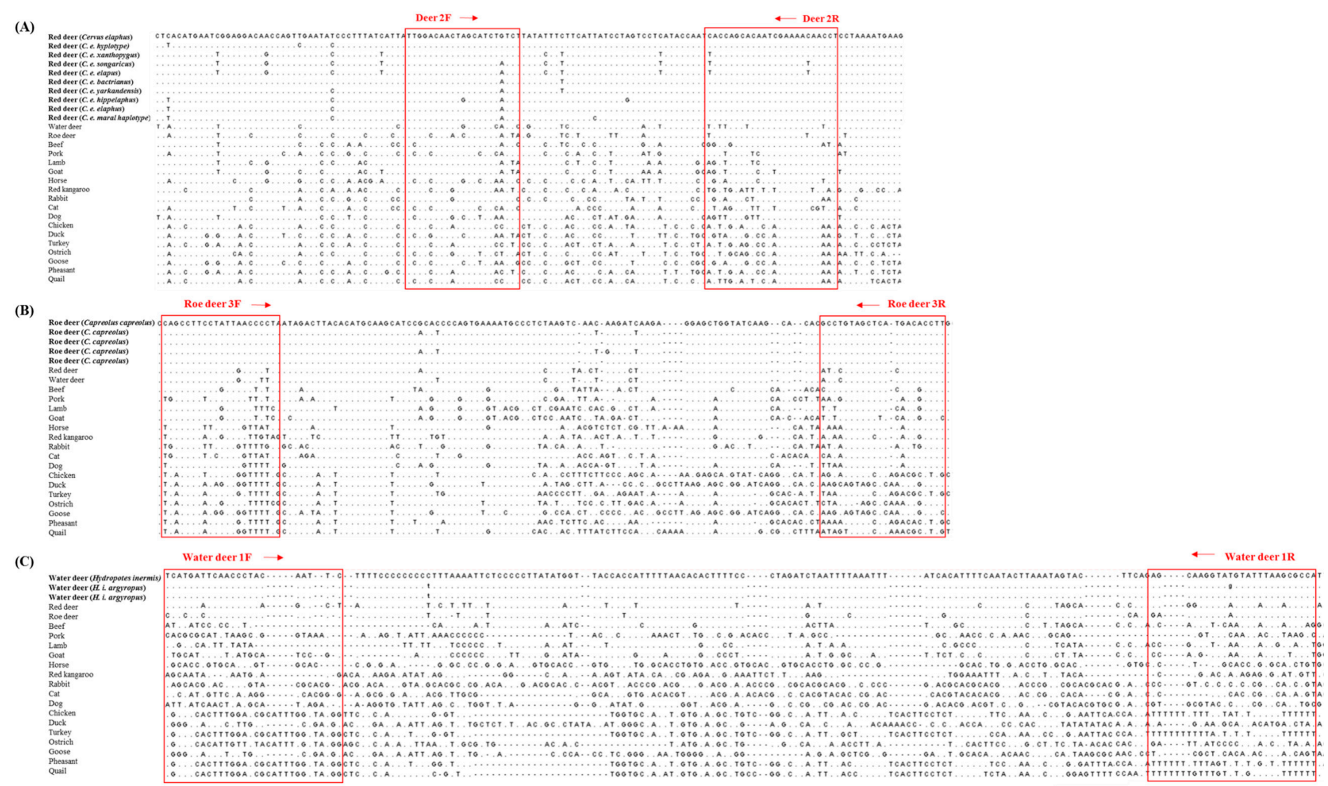

Figure 1. The sequence alignment of red $\operatorname{deer}(\mathbf{A})$, roe deer $(\mathbf{B})$, and water deer $(\mathbf{C})$ specific primers in the mitochondrial cytochrome b, $12 \mathrm{~S}$ rRNA, and D-loop regions against various animal species.

Table 1. Primers used in this study.

\begin{tabular}{|c|c|c|c|c|c|}
\hline Target Species & Primer Name & Sequences $\left(5^{\prime} \rightarrow 3^{\prime}\right)$ & Target Genes & Amplicon Size (bp) & Accession No. \\
\hline Red deer & $\begin{array}{l}\text { Deer } 2 \mathrm{~F} \\
\text { Deer } 2 \mathrm{R}\end{array}$ & $\begin{array}{c}\text { TGGACAACTAGCATCTGTCT } \\
\text { GAGGTTGTTTTCGATTGTGCTGGTG }\end{array}$ & cyt b & 79 & JF489133.1 \\
\hline Roe deer & $\begin{array}{l}\text { Roe deer } 3 \mathrm{~F} \\
\text { Roe deer } 3 \mathrm{R}\end{array}$ & $\begin{array}{l}\text { CAGCCTTCCTATTAACCCCT } \\
\text { AGGTGTCATGAGCTACAGGC }\end{array}$ & $12 \mathrm{~S}$ rRNA & 126 & KJ681490.1 \\
\hline Water deer & $\begin{array}{l}\text { Water deer } 1 \mathrm{~F} \\
\text { Water deer } 1 \mathrm{R}\end{array}$ & $\begin{array}{l}\text { CATGATTCAACCCTACAATTC } \\
\text { GGCGCTTAAATACATACCTTGCT }\end{array}$ & D-loop & 160 & NC011821 \\
\hline
\end{tabular}

\subsection{Single and Multiplex PCR Conditions}

Single PCR was performed in a $25 \mu \mathrm{L}$ final volume containing $10 \times$ Buffer (Bioneer, Daejeon, Korea), $10 \mathrm{mM}$ of dNTPs (Bioneer), 5 units of Hot Start Taq DNA polymerase (Bioneer), $0.4 \mu \mathrm{M}$ of each primer, and $10 \mathrm{ng}$ of DNA template. PCR reaction was carried out in a thermal cycler (Model PC 808, ASTEC, Fukuoka, Japan) as follows: pre-denaturation at $95^{\circ} \mathrm{C}$ for $5 \mathrm{~min}$, followed by 35 cycles of $95{ }^{\circ} \mathrm{C}$ for $30 \mathrm{~s}, 60^{\circ} \mathrm{C}$ for $30 \mathrm{~s}$, and $72{ }^{\circ} \mathrm{C}$ for $30 \mathrm{~s}$, with a final extension step at $72{ }^{\circ} \mathrm{C}$ for $5 \mathrm{~min}$.

PCR mixture for multiplex PCR was similar to single PCR except that it used 10 units of Hot Start Taq DNA polymerase (Bioneer) and optimized concentrations of primers. Annealing temperature concentrations of primers were optimized, considering specificity between three deer species. The annealing temperatures were estimated at 58, 59, 60, and $61{ }^{\circ} \mathrm{C}$, and the red deer/roe deer/water deer primers combinations were $0.2 / 0.4 / 0.4,0.2 / 0.4 / 0.5$, and $0.4 / 0.4 / 0.4 \mu \mathrm{M}$. Finally, 0.2 $\mu \mathrm{M}$ of primers for red deer and $0.4 \mu \mathrm{M}$ of primers for roe deer and water deer were used for multiplex PCR. Multiplex PCR reactions were carried out under the same conditions as single PCR. All PCR amplicons were electrophoresed on 3\% agarose gels stained with ethidium bromide at $150 \mathrm{~V}$ for $25 \mathrm{~min}$ and confirmed by capillary electrophoresis using an Agilent 2100 Bioanalyzer (Agilent Technologies, Santa Clara, CA, USA) with DNA 1000 Lab Chip kit (Agilent Technologies). Briefly, $1 \mu \mathrm{L}$ of PCR product and $5 \mu \mathrm{L}$ of markers were loaded into each of the 12 wells and applied with a gel-dye mix in the chip, which was run in the bioanalyzer.

\subsection{Specificity and Sensitivity of Multiplex PCR}

The specificity of each primer set was performed using DNAs (10 ng each) isolated from 10 animal samples, including red deer, roe deer, and water deer. The specificity of the developed multiplex 
PCR was conducted using DNAs of the three target species to determine whether there was any cross-reactivity between closely related species.

The sensitivity of multiplex PCR was estimated using serially diluted DNAs (from $10 \mathrm{ng}$ to 0.01 pg per reaction) of the three target species. Detection limits were tested using meat DNA mixtures. The ratio of DNA used in the mixture is shown in Table 2. This test was validated independently using different PCR instruments by different operators. All PCR reactions included a positive control (target DNA) and negative control (no-template).

Table 2. The ratio of meat DNA mixtures used in this study.

\begin{tabular}{cccc}
\hline & \multicolumn{2}{c}{ The Ratio of Meat DNA Mixtures (\%) } \\
\cline { 2 - 4 } & Red Deer & Roe Deer & Water Deer \\
\hline \multirow{2}{*}{ Roe deer and water deer } & 80 & 10 & 10 \\
in red deer & 90 & 5 & 5 \\
& 98 & 1 & 1 \\
& 99 & 0.5 & 0.5 \\
Red deer and roe deer & 99.8 & 0.1 & 0.1 \\
in water deer & 10 & 10 & 80 \\
& 5 & 5 & 90 \\
& 1 & 1 & 98 \\
& 0.5 & 0.5 & 99 \\
\hline
\end{tabular}

\section{Results and Discussion}

\subsection{The Specificity of Newly Designed Species-Specific Primers}

In this study, the species-specific primer sets targeting mitochondrial genes of cytochrome $\mathrm{b}, 12 \mathrm{~S}$ rRNA, and D-loop for red deer, roe deer, and water, respectively, were newly designed. As shown in Figure 1, sequences of each target species were compared with two closely related species and 16 other animal species. Considering the intraspecific variation of target species, each primer was selected to have specific sequences of target species (Figure 1). Primer design is very important in the development of multiplex PCR because the primer has to selectively amplify the target in a single reaction containing several primer sets [12]. For multiplex PCR, the sizes of PCR products amplified by each primer set were different for the three target species $(79,126$, and $160 \mathrm{bp}$ for red deer, roe deer, and water deer, respectively, Table 1). Each set of species-specific primers amplified only the target species without showing cross-reactivity with nine other species (Figure 2), demonstrating high primer specificity for the target species.

\subsection{Specificity and Sensitivity of Capillary Electrophoresis-Based Multiplex PCR}

Using these newly designed primers for the identification of red deer, roe deer, and water deer, a multiplex PCR was first optimized by adjusting the concentration of each primer and annealing temperature of PCR condition. The specificity of this optimized assay was then evaluated using DNAs isolated from 10 animal species. As shown in Figure 3, each primer set for red deer, roe deer, and water deer in CE-mPCR specifically amplified target species, showing a high resolution between target species. These results indicated that these red deer-, roe deer-, and water deer-specific primers were sufficient to differentiate these closely related three species by multiplex PCR without causing any cross-amplification against non-target species.

The sensitivity of this CE-mPCR developed in this study was evaluated using DNA at different amounts ranging from $10 \mathrm{ng}$ to $0.01 \mathrm{pg}$. The results are shown in Figure 4. In lane 6 of Figure 4, peaks of electropherogram were detected for red deer and water deer, but the peak of roe deer was not detected in lane 6 and shown in lane 5. Therefore, sensitivities for red deer, roe deer, and water 
deer were $0.1,1$, and $0.1 \mathrm{pg}$, respectively. Such high sensitivity of this assay might lead to accurate and reliable detection and differentiation of meat from three target deer species.
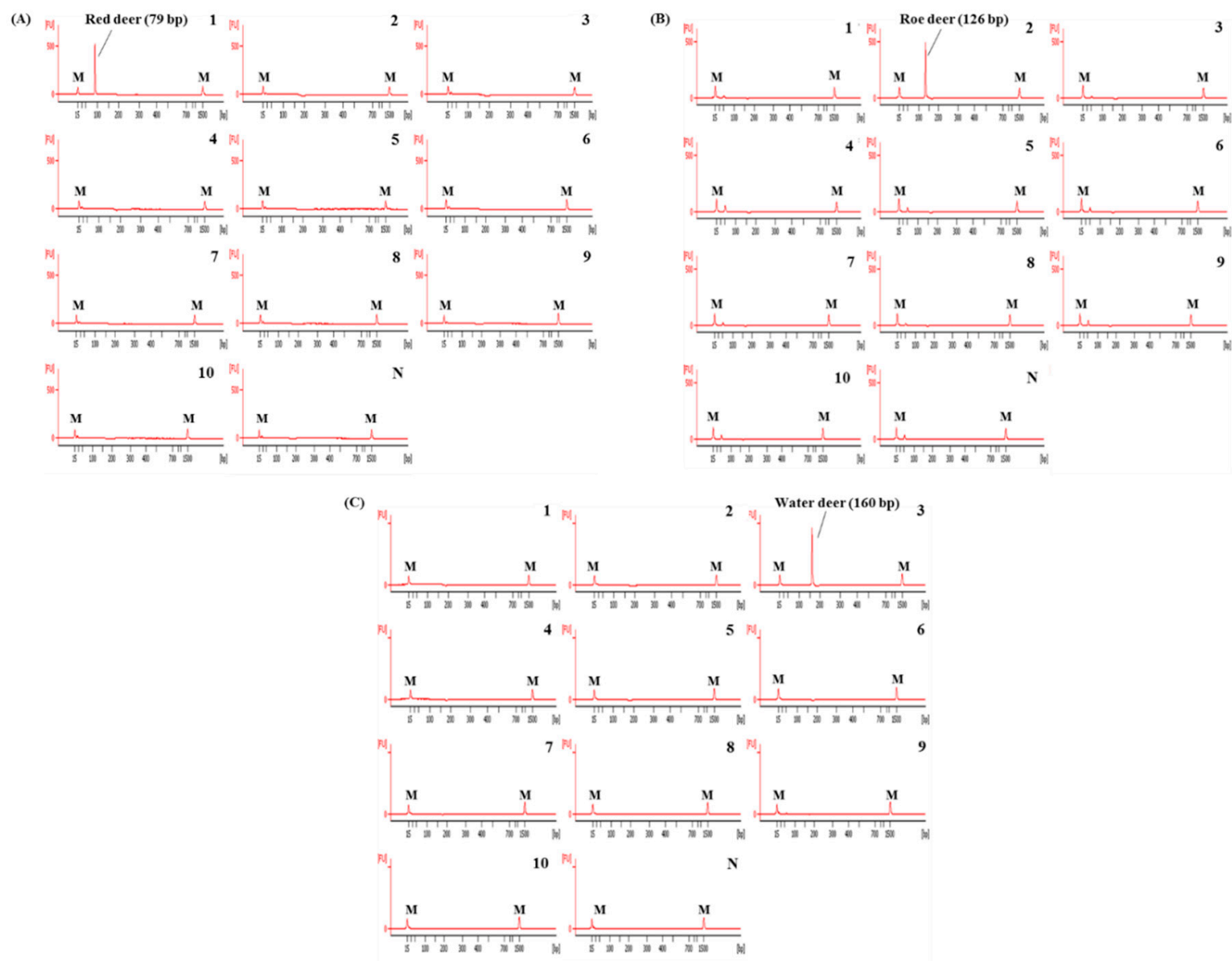

Figure 2. Electropherograms of specificity results of the single PCRs using newly designed primer sets for red deer (A), roe deer (B), and water deer (C). FU: fluorescence, M: alignment marker, lane 1: red deer, 2: roe deer, 3: water deer, 4: beef, 5: pork, 6: lamb, 7: goat, 8: horse, 9: chicken, 10: duck, and N: non-template.
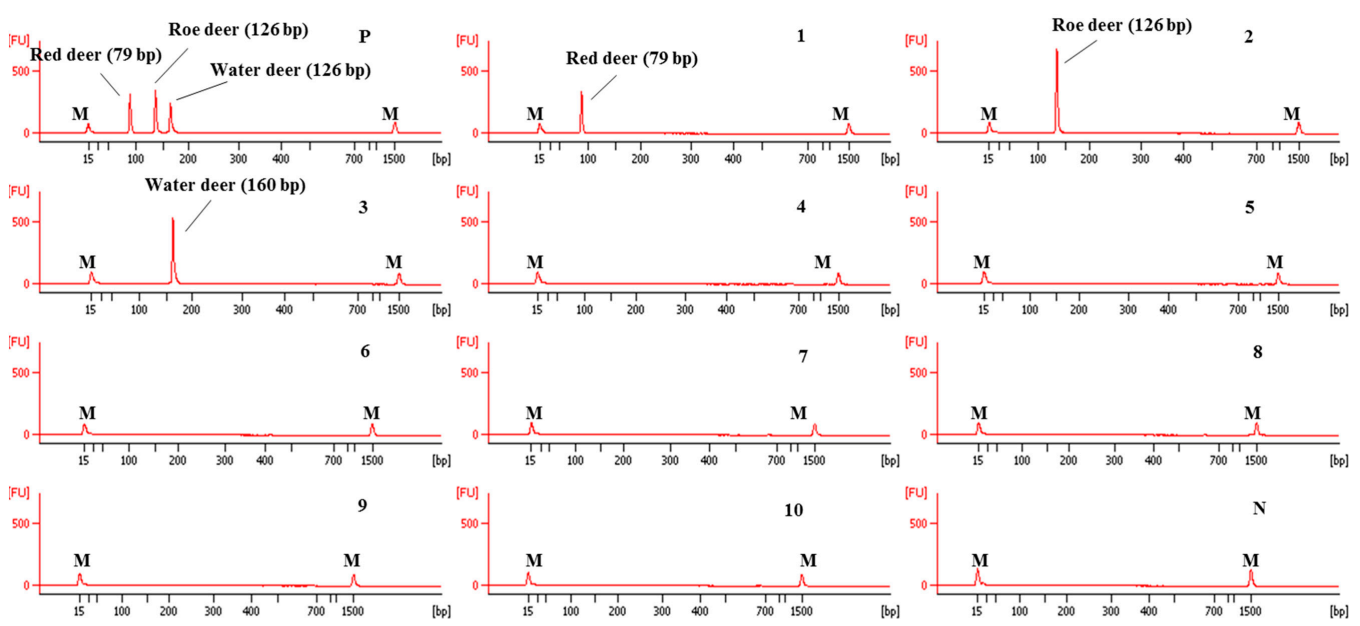

Figure 3. Electropherograms of specificity result of the multiplex PCR assay for red deer, roe deer, and water deer. FU: fluorescence, M: alignment marker, lane P: positive control (red deer, roe deer, and water deer), lane 1: red deer, 2: roe deer, 3: water deer, 4: beef, 5: pork, 6: lamb, 7: goat, 8: horse, 9: chicken, 10: duck, and N: non-template. 

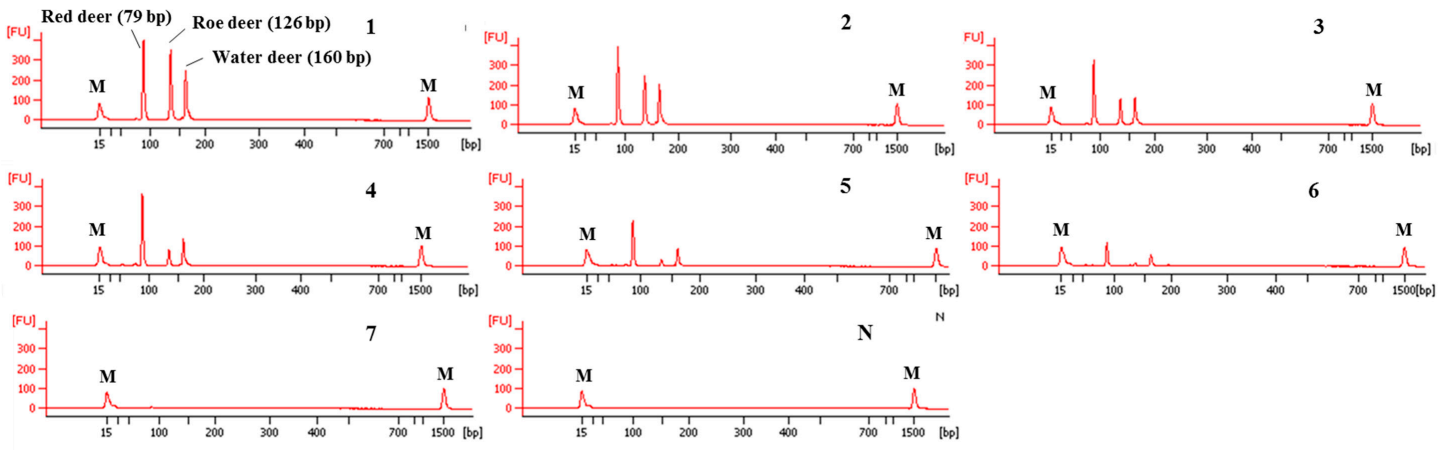

Figure 4. Electropherograms of sensitivity results of the multiplex PCR assay. FU: fluorescence, M: alignment marker, lanes 1-7: $1.0 \times 10^{1}, 10^{0}, 10^{-1}, 10^{-2}, 10^{-3}, 10^{-4}$, and $10^{-5}$ ng of three target species, and lane N: non-template.

\subsection{Application and Validation of Capillary Electrophoresis-Based Multiplex PCR Using Meat DNA Mixtures}

To determine detection limits of CE-mPCR and confirm its applicability to a real sample, two sets of meat DNA mixtures were prepared as follows: (1) roe deer and red deer commonly used as game meat were added in water deer to authenticate game meat species present in commercial deer meats, and (2) red deer was contaminated with roe deer and water deer to detect wild animal species not permitted commercially in several countries. As shown in Figure 5, the detection limit of this assay was at least $0.1 \%$ for roe deer and red deer in meat DNA mixtures. In another meat DNA mixture, as low as $0.1 \%$ of roe deer and water deer could be detected (Figure 6). Microchip-based capillary electrophoresis technology used in this study is known to provide better accuracy and resolution in multiple target detection [15]. In the present study, at a low concentration of $0.1 \%$ for water deer (lane 6 in Figure 6 ), the result obtained by capillary electrophoresis was clearer than a PCR band visualized on agarose gel (Figure S1). This can help overcome the drawback, such as a false-negative result. In addition, the detection limit was validated independently in duplicate. All results obtained through intra-laboratory validation analysis were similar. The $0.1 \%$ of roe deer and red deer mixed in water deer and $0.1 \%$ of roe deer and water deer mixed in red deer were detected in two independent PCR reactions using the developed primer sets. Thus, this CE-mPCR assay developed in this study was able to simultaneously detect up to $0.1 \%$ of red deer, roe deer, and water deer in meat DNA mixtures. Compared to the limit of detection of $0.1 \%$ for roe deer and red deer [4] and $0.5 \%$ for red deer [3], our method showed higher or similar sensitivity. Meanwhile, since this was the first study to apply a detection method for water deer to meat DNA mixtures, the detection limit of $0.1 \%$ of our developed method could not be compared to previous reports. However, this method might be sufficient to be utilized as a specific and sensitive molecular tool for monitoring these three types of deer meat.

(A)

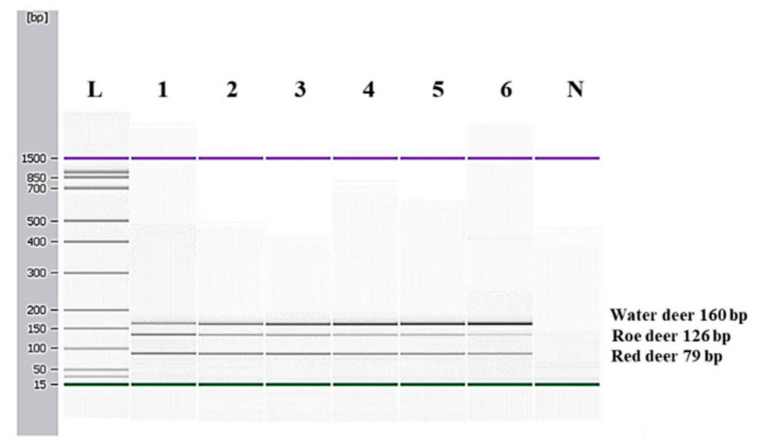


(B)

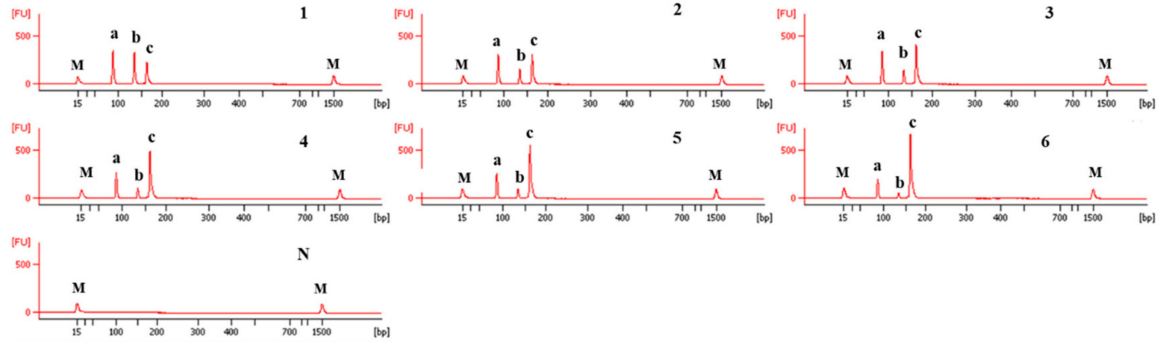

Figure 5. Detection limits of red deer and roe deer in water deer by the multiplex PCR assay. Gel image (A) and electropherograms (B). FU: fluorescence, M: alignment marker, lane L: 100 bp DNA ladder, lane 1: positive control (10 ng of DNA from target species), lanes 2-6: 10, 5, 1, 0.5, and 0.1\% red deer and roe deer in water deer, and lane N: non-template. $\mathrm{a}, \mathrm{b}$, and c indicate red deer, roe deer, and water deer, respectively.

(A)

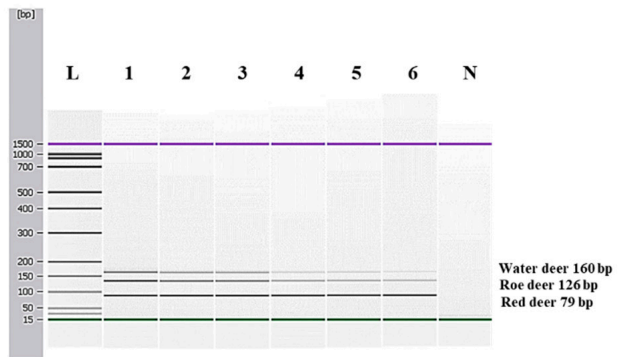

(B)

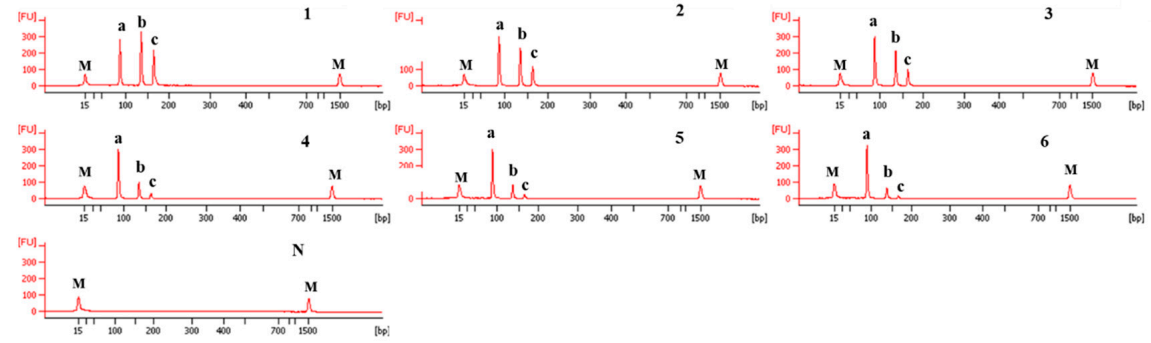

Figure 6. Detection limits of roe deer and water deer in red deer by the multiplex PCR assay. Gel image (A) and electropherograms (B). FU: fluorescence, M: alignment marker, lane L: 100 bp DNA ladder, lane 1: positive control (10 ng of each DNA from target species), lanes 2-6: 10, 5, 1, 0.5, and 0.1\% roe deer and water deer in red deer, and lane N: non-template. $\mathrm{a}, \mathrm{b}$, and c indicate red deer, roe deer, and water deer, respectively.

\section{Conclusions}

The CE-mPCR assay developed in this study could successfully detect three types of deer meat. Its applicability for authentication of meat species was verified using various ratios of meat DNA mixtures. This method is simple and user-friendly. It has high specificity and sensitivity for the simultaneous detection of red deer, roe deer, and water deer. However, despite several advantages of this method developed, since it is utilized for only qualitative detection, further study is required to the application of real-time PCR to quantify meat of target deer species in processed game meat.

Supplementary Materials: The following are available online at http://www.mdpi.com/2304-8158/9/8/982/s1. Figure S1: Detection limits of the multiplex PCR assay. Lane M: 100 bp DNA ladder, lanes 1: positive control (10 ng of each DNA from target species), lanes 2-6: 10,5, 1, 0.5, and $0.1 \%$ roe deer and water deer in red deer, and lane N: non-template. Table S1: Mitochondrial gene sequences of various animals used for the sequence alignment.

Author Contributions: Formal analysis, M.-J.K., Y.-M.L., and S.-M.S.; Funding acquisition, H.-Y.K.; Methodology, M.-J.K.; Project administration, H.-Y.K.; Supervision, H.-Y.K.; Validation, Y.-M.L.; Writing-original draft, M.-J.K.; Writing-review and editing, M.-J.K., Y.-M.L., S.-M.S., and H.-Y.K. All authors have read and agreed to the published version of the manuscript. 
Funding: This research was funded by the Ministry of Food and Drug Safety in Korea, grant number 17162MFDS065.

Acknowledgments: This research was supported by a grant (17162MFDS065) from the Ministry of Food and Drug Safety in Korea.

Conflicts of Interest: The authors declare no conflict of interest.

\section{References}

1. Rahmati, S.; Julkapli, N.M.; Yehye, W.A.; Basirun, W.J. Identification of meat origin in food products-A review. Food Control 2016, 68, 379-390. [CrossRef]

2. Kim, M.J.; Suh, S.M.; Kim, S.Y.; Qin, P.; Kim, H.R.; Kim, H.Y. Development of a real-time PCR assay for the detection of donkey (Equus asinus) meat in meat processing conditions. Foods 2020, 9, 130. [CrossRef]

3. Druml, B.; Grandits, S.; Mayer, W.; Hochegger, R.; Cichna-Markl, M. Authenticity control of game meat products-A single method to detect and quantify adulteration of fallow deer (Dama dama), red deer (Cervus elaphus) and sika deer (Cervus Nippon) by real-time PCR. Food Chem. 2015, 170, 506-517. [CrossRef]

4. Kaltenbrunner, M.; Hochegger, R.; Cichna-Markl, M. Tetraplex real-time PCR assay for the simultaneous identification and quantification of roe deer, red deer, fallow deer and sika deer for deer meat authentication. Food Chem. 2018, 269, 486-494. [CrossRef]

5. Fajardo, V.; Conzalez, I.; Martin, I.; Rojas, M.; Hernandez, P.E.; Garcia, T.; Martin, R. Real-time PCR for detection and quantification of red deer (Cervus elaphus), fallow deer (Dama dama), and roe deer (Capreolus capreolus) in meat mixtures. Meat Sci. 2008, 79, 289-298. [CrossRef]

6. Kaltenbrunner, M.; Hochegger, R.; Cichna-Markl, M. Development and validation of a fallow deer (Dama dama)-specific TaqMan real-time PCR assay for the detection of food adulteration. Food Chem. 2018, 243, 82-90. [CrossRef]

7. Druml, B.; Hochegger, R.; Cichna-Markl, M. Duplex real-time PCR assay for the simultaneous determination of the roe deer (Capreolus capreolus) and deer (sum of fallow deer, red deer and sika deer) content in game meat products. Food Control 2015, 57, 370-376. [CrossRef]

8. Koppel, R.; Van Velsen, F.; Ganeshan, A.; Pietsch, K.; Weber, S.; Graf, C.; Murmann, P.; Hochegger, R.; Licina, A. Multiplex real-time PCR for the detection and quantification of DNA from chamois, roe, deer, pork and beef. Eur. Food Res. Technol. 2020, 246, 1007-1015. [CrossRef]

9. Kim, M.J.; Yoo, I.; Lee, S.Y.; Hong, Y.; Kim, H.Y. Quantitative detection of pork in commercial meat products by TaqMan real-time PCR assay targeting the mitochondrial D-loop region. Food Chem. 2016, 210, 102-106. [CrossRef]

10. Jiang, X.; Rao, Q.; Mittl, K.; Hsieh, Y.H.P. Monoclonal antibody-based sandwich ELISA for the detection of mammalian meats. Food Control 2020, 110, 107045. [CrossRef]

11. Chou, C.C.; Lin, S.P.; Lee, K.M.; Hsu, C.T.; Vickroy, T.W.; Zen, J.M. Fast differentiation of meats from fifteen animal species by liquid chromatography with electrochemical detection using copper nanoparticle plated electrodes. J. Chromatogr. B. 2007, 846, 230-239. [CrossRef]

12. Varani, M.; Faccini, A.; Lambertini, F.; Suman, M.; Laporati, A.; Tedeschi, T.; Sforza, S. Species specific marker peptides for meat authenticity assessment: A multispecies quantitative approach applied to Bolognese sauce. Food Control 2019, 97, 15-24.

13. Soares, S.; Amaral, J.S.; Oliveira, M.B.; Mafra, I. A SYBR Green real-time PCR assay to detect and quantify pork meat in processed poultry meat products. Meat Sci. 2013, 94, 115-120. [CrossRef]

14. Kim, M.J.; Kim, H.Y. A fast multiplex real-time PCR assay for simultaneous detection of pork, chicken, and beef in commercial processed meat products. LWT-Food Sci. Technol. 2019, 114, 108390. [CrossRef]

15. Ali, M.E.; Razzak, M.A.; Hamid, S.B.; Rahman, M.M.; Amin, M.A.; Rashid, N.R. Multiplex PCR assay for the detection of five meat species forbidden in Islamic foods. Food Chem. 2015, 177, 214-224. [CrossRef]

16. Kim, M.J.; Yoo, I.; Yang, S.M.; Suh, S.M.; Kim, H.Y. Development and validation of a multiplex PCR assay for simultaneous detection of chicken, turkey, and duck in processed meat products. Int. J. Food Sci. Technol. 2018, 53, 2673-2679. [CrossRef]

17. Kim, M.J.; Kim, S.Y.; Jung, S.K.; Kim, M.Y.; Kim, H.Y. Development and validation of ultrafast PCR assays to detect six species of edible insects. Food Control 2019, 103, 21-26. [CrossRef] 
18. Park, S.H.; Ricke, S.C. Development of multiplex PCR assays for simultaneous detection of Salmonella genus, Salmonella subspecies I., Salm. Eteritidis, Salm. Heidelberg and Salm. Typhimurium. J. Appl. Micobiol. 2015, 118, 152-160. [CrossRef]

19. Rak, L.; Knapik, K.; Bania, J.; Sukowski, J.; Gadzinowski, A. Detection of roe deer, red deer, and hare meat in raw materials and processed products available in Poland. Eur. Food Res. Technol. 2014, 239, 189-194. [CrossRef]

20. Hou, B.; Meng, X.; Zhang, L.; Guo, J.; Li, S.; Jin, H. Development of a sensitive and specific multiplex PCR method for the simultaneous detection of chicken, duck and goose DNA in meat products. Meat Sci. 2015, 101, 90-94. [CrossRef] [PubMed]

21. Kim, M.J.; Kim, H.Y. Species identification of commercial jerky products in food and feed using direct pentaplex PCR assay. Food Control 2017, 78, 1-6. [CrossRef]

22. Kitpipit, T.; Sittichan, K.; Thanakiatkrai, P. Direct-multiplex PCR assay for meat species identification in food products. Food Chem. 2014, 163, 77-82. [CrossRef] [PubMed]

23. Lin, W.F.; Hwang, D.F. A multiplex PCR assay for species identification of raw and cooked bonito. Food Control 2008, 19, 879-885. [CrossRef]

24. He, H.; Hong, X.; Feng, Y.; Wang, Y.; Ying, J.; Liu, Q.; Qian, Y.; Zhou, X.; Wang, D. Application of Quadruple Multiplex PCR Detection for Beef, Duck, Mutton and Pork in Mixed Meat. J. Food Nutr. Res. 2015, 3, 392-398. [CrossRef]

25. Hossain, M.M.; Ali, M.E.; Hamid, S.B.A.; Mustafa, S.; Desa, M.N.M.; Zaidul, I.S.M. Targeting double genes in multiplex PCR for discriminating bovine, buffalo and porcine materials in food chain. Food Control 2017, 73, 175-184. [CrossRef]

26. Suh, S.M.; Kim, M.J.; Kim, H.I.; Kim, H.J.; Kim, H.Y. A multiplex PCR assay combined with capillary electrophoresis for the simultaneous detection of tropomyosin allergens from oyster, mussel, abalone, and clam mollusk species. Food Chem. 2020, 317, 126451. [CrossRef]

(C) 2020 by the authors. Licensee MDPI, Basel, Switzerland. This article is an open access article distributed under the terms and conditions of the Creative Commons Attribution (CC BY) license (http://creativecommons.org/licenses/by/4.0/). 